TELAGA BAHASA

Volume 5

No. 1 Juni 2017

Halaman 49-62

\title{
MENINGKATKAN HASIL BELAJAR MATA PELAJARAN BAHASA INDONESIA MELALUI PEMBELAJARAN BERBASIS LINGKUNGAN PADA PESERTA DIDIK KELAS VII - 4 SMP NEGERI 8 GORONTALO
}

\section{(Increasing The Result Of Study Of Subject Bahasa Indonesia Through Environment Based Learning To Class Vii-4 Students Of Smpn 8 Gorontalo)}

\author{
Hasna Isa \\ Guru SMP Negeri 8 Gorontalo \\ Kota Gorontalo
}

\begin{abstract}
Abstrak
Penelitian ini bertujuan meningkatkan hasil belajar peserta didik. Masalah dalam Penelitian Tindakan Kelas ini adalah bagaimana meningkatkan hasil belajar peserta didik melalui pembelajaran berbasis lingkungan. Pelaksanaan Penelitian Tindakan Kelas terdiri dari 2 siklus. Prosedur pelaksanaan Penelitian Tindakan Kelas ada empat tahap, yaitu (a) persiapan tindakan, (b) pelaksanaan tindakan, (c) pemantauan dan evaluasi, (d) analisis dan refleksi. Hasil pelaksanaan Penelitian Tindakan Kelas dipaparkan berikut .Pada siklus I proses pelaksanaan tindakan mencapai 70 $\%$ dan hasil belajar mencapai $75,6 \%$ atau 25 orang siswa yang tuntas. Pada siklus II diperoleh proses pelaksanaan tindakan $87,5 \%$ dan hasil belajar $87,9 \%$ atau 28 orang siswa yang tuntas.
\end{abstract}

Dari hasil pelaksanaan ini dapat disimpulkan, bahwa penerapan pembelajaran berbasis lingkungan dapat meningkatkan hasil belajar peserta didik pada mata pelajaran Bahasa Indonesia.

Kata kunci: hasil belajar, berbasis lingkungan

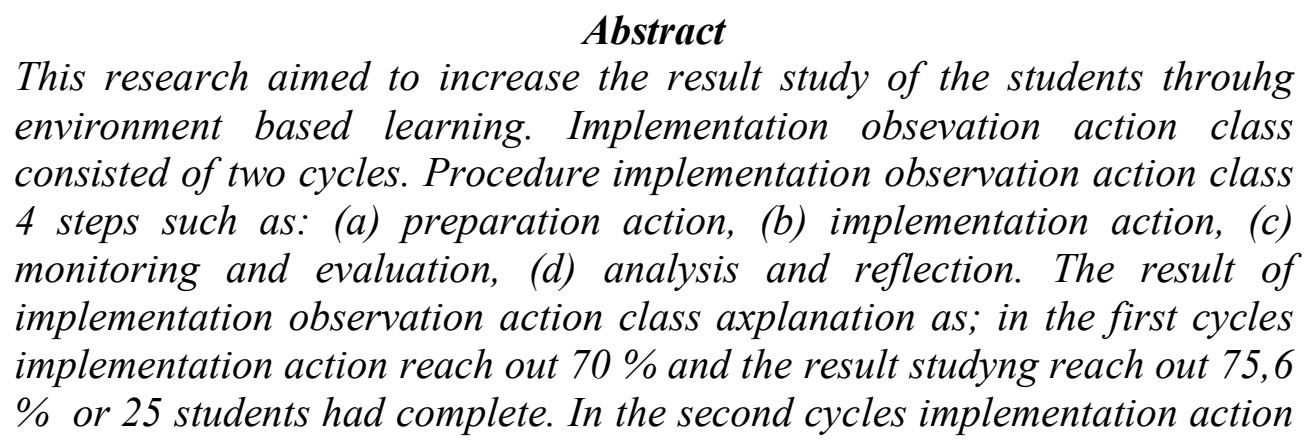


reached out $87.5 \%$ and the result studyng $87,9 \%$ or 28 students had complete.

From the result inmplementation observation action class, it can be concluded that assembling studying based of environment increases the result studying students in Bahasa Indonesia.

Keywords: the result studying, environment based

\section{PENDAHULUAN}

Berbagai upaya telah dilakukan untuk meningkatkan mutu pendidikan nasional, antara lain melalui berbagai pelatihan dan peningkatan kualifikasi guru, penyempurnaan kurikulum, pengadaan buku dan alat pelajaran, perbaikan sarana dan prasarana pendidikan lainnya serta peningkatan mutu manajemen sekolah. Namun demikian, berbagai indikator mutu pendidikan belum menunjukkan peningkatan yang memadai.

Berdasarkan hal itu, pembaharuan pendidikan harus selalu dilakukan. Dalam konteks pembaharuan pendidikan, ada tiga hal utama yang perlu disoroti, yaitu pembaharuan kurikulum, peningkatan kualitas pembelajaran dan efektivitas metode/model pembelajaran, Murhadi, dkk (2004). Kualitas pembelajaran harus ditingkatkan untuk peningkatan hasil pendidikan. Secara mikro harus ditemukan strategi atau model pembelajaran yang efektif yang lebih memberdayakan potensi peserta didik. Peserta didik dibantu agar kompetensi yang dimilikinya muncul dan dikembangkan semaksimal mungkin. Untuk mengembangkan kompetensi yang dimiliki peserta didik, guru harus mampu melakukan berbagai terobosan dalam meningkatkan proses dan hasil pembelajran. Guru harus mampu memahami keberadaan peserta didik yang memiliki banyak kelebihan dan kelemahan.

Berdasarkan pengalaman, kegiatan pembelajaran bahasa Indonesia selama ini masih sering mengalami masalah. Hal ini terlihat dari suasana kelas terasa sepi, peserta didik terkesan pasif dalam belajar bahkan peserta didik kurang bergairah belajar. Penyebab permasalahannya adalah pembelajaran yang dilakukan selama ini tidak dapat membangkitkan gairah dan keaktifan belajar peserta didik. Pembelajaran lebih banyak menggunakan metode ceramah dan mendikte peserta didik sehingga peserta didik merasa seakan berada di dalam ruang tahanan. Peserta didik tidak memperoleh kesempatan belajar secara leluasa. Guru menganggap bahwa proses pembelajaran 
hanya berlangsung di dalam kelas. Tembok sekolah menjadi benteng yang kuat, yang membatasi hubungan dengan masyarakat. Ruangan kelas dipandang sebagai ruang penyelamat, ruang memberi kehidupan, dan belajar di dalam batas-batas ruangan itu adalah belajar yang paling baik. Pembelajaran di luar kelas sama sekali tak pernah dilakukan. Guru kurang memahami bahwa dunia anak adalah dunia bermain, sehingga anak atau peserta didik lebih senang belajar di luar kelas dibanding belajar dalam kelas. Hal seperti ini menyebabkan timbulnya kejenuhan pada diri peserta didik yang pada akhirnya berpengaruh pula pada hasil belajarnya.

Untuk mengatasi kendala yang muncul sebagaimana dikemukakan di atas, penulis menerapkan pendekatan pembelajaran yang dapat membangkitkan motivasi belajar serta menghilangkan kejenuhan peserta didik. Pendekatan yang dimaksudkan adalah "pembelajaran berbasis lingkungan". Pendekatan ini dipilih agar suasana pembelajaran menyenangkan bagi peserta didik. Peserta didik akan termotivasi dan lebih aktif belajar serta mudah menyerap materi yang diberikan.

Penelitian meningkatkan motivasi belajar peserta didik,2) meningkatkan keatifan peserta didik dalam kegiatan pembelajaran, 3) meningkatkan suasana belajar menyenangkan bagi peserta didik, 4) meningkatkan hasil belajar pada mata pelajaran bahasa Indonesia, dan 5) meningkatkan kemampuan dan pemahaman guru dalam menyusun program pembelajaran dan memilih strategi pembelajaran yang tepat. Penelitian ini diharapkan dapat menjadi salah satu solusi untuk hasil belajar peserta didik pada mata pelajaran Bahasa Indonesia.

\section{TEORI}

\section{Hakikat Belajar dan Pembelajaran}

Menurut Dimyati dan Modjono (1994:7), belajar merupakan tindakan dan perilaku siswa yang kompleks. Sebagai tindakan, maka belajar hanya dialami oleh siswa sendiri. Siswa adalah penentu terjadinya atau tidak terjadinya proses belajar. Proses belajar terjadi berkat siswa memperoleh sesuatu yang ada di lingkungan sekitar.

Pendapat yang sama juga dikemukakan oleh Pagne (dalam Dimyati, 1994 : 10). Pagne berpendapat bahwa belajar merupakan kegiatan yang kompleks. Kompleksitas belajar dapat dipandang dari dua segi, yaitu (1) dari segi siswa, belajar dialami sebagai suatu proses. Siswa mengalami proses mental dalam menghadapi bahan belajar, (2) dari segi guru, proses 
belajar tersebut tampak sebagai perilaku belajar tentang sesuatu hal.

Pendapat yang lain dikemukakan oleh Hamalik (2006: 27), yakni 1) belajar merupakan suatu proses, suatu kegiatan dan bukan suatu hasil atau tujuan. 2) belajar adalah suatu proses perubahan tingkah laku individu melalui interaksi dengan lingkungan.

Dari beberapa pendapat yang dikemukakan dapat disimpulkan bahwa belajar adalah suatu proses tindakan dan perilaku siswa dalam mempelajari sesuatu secara kompleks melalui interaksi antara individu dengan lingkungan $\mathrm{Di}$ dalam interaksi inilah terjadi serangkaian pengalaman-pengalaman belajar. Proses belajar dapat diamati secara tidak langsung. Artinya proses belajar merupakan proses internal siswa yang tidak dapat diamati, tetapi dapat dipahami oleh guru.

Dalam kegiatan pembelajaran, siswa adalah subjek dan sebagai objek. Oleh karena itu, proses pembelajaran tidak lain adalah kegiatan belajar siswa dalam mencapai suatu tujuan pembelajaran (Bahri dan Aswan, 2006:38). Tujuan pembelajaran akan tercapai jika siswa berusaha secara aktif untuk mencapainya. Karena pada hakikatnya pembelajaran adalah suatu proses, yaitu proses mengatur, mengorganisasi lingkungan yang ada di sekitar peserta didik, sehingga dapat menumbuhkan dan mendorong peserta didik melakukan proses belajar. Proses belajar tersebut terjadi lewat perilaku peserta didik mempelajari bahan belajar. Oleh karena itu bahan belajar yang akan dibelajarkan kepada peserta didik hendaknya terencana dengan baik dan mengacu pada kurikulum yang berlaku.

\section{Hasil Belajar}

Hasil belajar adalah kemampuan yang diperoleh peserta didik setelah melalui kegiatan belajar. Belajar itu sendiri merupakan suatu proses dan seseorang yang berusaha untuk memperoleh suatu bentuk perubahan perilaku yang relatif menetap (Mulyono, 1999;38). Dalam kegiatan belajar yang terprogram dan terkontrol yang disebut kegiatan pembelajaran, tujuan belajar telah ditetapkan lebih dulu oleh guru. Peserta didik yang berhasil dalam belajar ialah yang berhasil mencapai tujuan-tujuan pembelajaran. Tujuan yang dirumuskan harus benar-benar memperhatikan kesinambungan setiap jenjang tujuan dalam pembelajaran. Agar dapat mencapai tujuan secara optimal, maka dalam melakukan interaksi perlu ada prosedur, atau langkah-langkah sistematik dan relevan. Roestiyah (dalam Bahri dan Aswan, 2006:42) mengatakan bahwa suatu tujuan pembelajaran adalah deskripsi tentang performance siswa yang diharapkan setelah 
mereka melakukan proses belajar. Artinya bahwa yang diharapkan dari siswa adalah hasil belajar yang diperolehnya setelah melakukan proses belajar.

Pendapat yang sama juga dikemukakan oleh Romistowski (dalam Mulyono, 1999;38), bahwa hasil belajar merupakan keluaran (output) dari suatu sistem pemprosesan masukan (input). Masukan dari sistem tersebut berupa bermacam-macam informasi sedangkan keluarannnya adalah perbuatan atau kinerja. Perubahan merupakan petunjuk bahwa proses belajar telah terjadi, dan hasil belajar adalah pengetahuan dan keterampilan.

Dari pendapat di atas, dapat dikatakan bahwa hasil belajar adalah pengetahuan, keterampilan yang diperoleh peserta didik setelah melalui proses pembelajaran. Hasil belajar juga dipengaruhi oleh intelegensi dan penguasaan awal peserta didik tentang materi yang akan dipelajari. Hal ini berbarti bahwa guru hendaknya menetapkan tujuan belajar sesuai dengan kapasitas yang diberikan kepada peserta didik. Hasil belajar dapat dipengaruhi oleh adanya kesempatan yang diberikan kepada peserta didik. Ini berarti bahwa guru perlu menyusun rancangan dan pengelolaan pembelajaran yang memungkinkan peserta didik untuk melakukan eksplorasi terhadap lingkungannya. Peserta didik akan mencapai hasil belajar yang maksimal apabila guru benar-benar menyusun rencana pembelajaran dengan baik sesuai komponenkomponen pembelajaran yang ditetapkan.

\section{Pembelajaran Berbasis Lingkungan}

Belajar pada hakikatnya adalah suatu interaksi antara individu dan lingkungan. Lingkungan menyediakan rangsangan (stimlus) terhadap individu dan sebaliknya individu memberikan respons terhadap lingkungan (Hamalik, 2001:194). Dalam proses interaksi itu, dapat terjadi perubahan pada diri individu berupa perubahan tingkah laku. Dapat juga terjadi, individu menyebabkan terjadinya perubahan pada lingkungan, baik yang positif atau bersifat negatif. Hal ini menunjukkan bahwa fungsi lingkungan merupakan faktor yang penting dalam proses belajar mengajar.

$$
\text { Sedangkan Djaali }
$$
mengatakan bahwa dalam proses belajar yang diutamakan adalah bagaimana individu dapat menyesuaikan diri terhadap rangsangan lingkungan kemudian individu itu mengadakan reaksi. Reaksi yang dilakukan merupakan usaha untuk menciptakan kegiatan sekaligus menyelesaikannya, dan akhirnya mendapatkan hasil yang mengakibatkan perubahan pada dirinya sebagai hal baru serta menambah pengetahuan. 
Tokoh-tokoh pendidikan masa lampau berpandangan bahwa faktor lingkungan sangat bermakna dan dijadikan sebagai landasan dalam mengembangkan konsep pendidikan dan pengajaran. Rousseau (dalam Hamalik, 2001:194) dengan teorinya "Kembali ke Alam" menunjukkan betapa pentingnya pengaruh alam terhadap perkembangan anak didik. Pendapat yang sama juga dikemukakan oleh Ligthart yang terkenal dengan "Pengajaran Alam Sekitar". Menurutnya, pendidikan sebaiknya disesuaikan dengan keadaan alam sekitar. Alam sekitar adalah segala sesuatu yang ada di sekitar kita. Pengajaran berdasarkan alam sekitar akan membantu peserta didik untuk menyesuaikan dirinya dengan keadaan sekitarnya.

Pendapat senada dikemukakan oleh Decroly, ia terkenal dengan teorinya "sekolah adalah dari kehidupan dan untuk kehidupan. Dikemukakan bahwa, bawalah kehidupan ke dalam sekolah agar kelak anak didik dapat hidup di masyarakat." Pandangan ketiga tokoh pendidikan tersebut sedikit banyak menggambarkan, bahwa lingkungan merupakan dasar pendidikan pengajaran yang penting, bahkan dengan dasar ini dapat dikembangkan suatu model persekolahan yang berorientasi pada lingkungan masyarakat.
Lingkungan adalah salah satu sumber kehidupan. Sebagai sumber kehidupan, seseorang menjalankan segala aktivitas tidak akan lepas dari lingkungan sekitar. Demikian halnya dengan pembelajaran di sekolah. Proses pembelajaran di sekolah perlu memanfaatkan lingkungan sebagai sumber belajar. Proses pembelajaran tidak hanya berlangsung di dalam kelas, tetapi juga dapat berlangsung di luar kelas dengan memanfaatkan lingkungan sekitar untuk mencapai tujuan pembelajaran. Guru harus menciptakan suatu lingkungan di mana peserta didik dapat merefleksikan bagaimana mereka belajar, menyelesaikan tugas-tugas sekolah, menghadapi hambatan, dan bekerja sama secara harmonis dengan guru yang lainnya, Nurhadi, dkk (2004: 21).

Lingkungan sekolah yang baik adalah lingkungan sekolah yang di dalamnya dihiasi dengan tanaman/pepohonan yang dipelihara dengan baik (Djamarah,2008). Kesejukan lingkungan membuat peserta didik betah tinggal berlama-lama di dalamnya. Seperti itulah lingkungan sekolah yang dikehendai sehingga peserta didik akan lebih leluasa dalam belajar. Suatu lingkungan belajar yang kaya perlu diciptakan untuk meningkatkan pembelajaran bagi peserta didik (Mohamad Nur,2004). Para guru seyogyanya mampu menciptakan dan memanfaatkan lingkungan sebagai sumber belajar agar peserta didik 
mudah memperoleh bahan belajar karena bahan yang diambilkan berasal dari dunia nyata peserta didik.

Lingkungan sebagai dasar pengajaran adalah faktor kondisional yang mempengaruhi tingkah laku individu dan merupakan faktor belajar yang penting. Lingkungan belajar/ pembelajaran terdiri dari berikut ini; (1) Lingkungan sosial. (2) lingkungan personal.,(3) Lingkungan alam.(4) lingkungan cultural. Disamping itu pula lingkungan pembelajaran mempunyai fungsi sebagai berikut; 1) fungsi psikologis, 2) fungsi pedagogis, dan 3) fungsi instruksional. Suatu dimensi lingkungan yang sangat penting adalah masyarakat. Dalam konteks ini masyarakat mencakup unsurr-unsur individu, kelompok, sumbersumber alami, sumber budaya, system nilai dan norma, kondisi/situasi serta masalahmasalah, dan berbagai hambatan dalam masyarakat, secara keseluruhan merupakan lingkungan masyarakat.

Dilihat dari dimensi lingkungan ada dua faktor yang dapat mempengaruhi proses pembelajaran, yaitu faktor organisasi kelas dan faktor iklim sosial-psikologis, Sanjaya (2006:56). Faktor organisasi kelas yang di dalamnya meliputi jumlah peserta didik dalam satu kelas merupakan aspek penting yang bisa mempengaruhi proses pembelajaran. Peserta didik akan jenuh belajar di dalam kelas pada kondisi kelas yang sangat padat. Oleh karena itulah guru senantiasa memahami kondisi peserta didik yang dapat mempengaruhi proses dan hasil belajarnya. Guru harus mampu memikirkan kondisi belajar yang memungkinkan peserta didik untuk lebih leluasa dalam belajar, karena pembelajaran tidak harus terjadi di dalam kelas tetapi dapat pula di luar kelas. Jika pembelajaran dapat dilaksanakan di luar kelas maka guru dan peserta didik dapat memanfaatkan lingkungan sebagai sumber belajar. Bahkan Abdurahman ( 2007:94) menyatakan bahwa, pembelajaran diarahkan pada environmental based learning (memperhatikan lingkungan peserta didik sebagai suatu media belajar)

Guru mengajak terlibat langsung kepada lingkungan bersama peserta didik atau dapat pula melakukan penugasan yang dapat dilakukan di berbagai konteks lingkungan peserta didik antara lain di sekolah, keluarga, dan masyarakat. Hal ini akan lebih membantu peserta didik untuk mengerti benar pada kehidupan nantinya bahwa belajar itu sumbernya adalah lingkungan dan dunia secara keseluruhan. Selanjutnya belajar berbasis lingkungan ini juga ditujukan agar nantinya peserta didik benar-benar menjadi peserta didik yang peka perubahan sekitar sehingga bisa memberikan kontribusi baru bagi lingkungannya. Hal 
semacam ini akan memberikan kesempatan bagi peserta didik untuk belajar di luar kelas. Sebab biasanya bagi peserta didik, belajar terjun ke lapangan adalah lebih menyenangkan ketimbang terkungkung di dalam kelas.

Menurut

Finger

(dalam

Sagala,2003:180) pembelajaran yang mendekatkan siswa dengan lingkungan sekitar adalah pembelajaran alam sekitar. Dengan pembelajaran alam sekitar, guru dapat memperagakan secara langsung sesuai dengan sifat-sifat atau dasar-dasar pembelajaran. Pembelajaran alam sekitar memberikan kesempatan sebanyakbanyaknya agar siswa aktif atau lebih giat dalam mengikuti proses pembelajaran.

Dari beberapa pendapat yang telah diuraikan, dapat disimpulkan bahwa pembelajaran berbasis lingkungan adalah pembelajaran yang mendekatkan peserta didik dengan lingkungan sekitar dan memanfaatkan lingkungan itu sebagai sumber belajar sehingga tercipta suasana menyenangkan bagi peserta didik.

Pembelajaran alam sekitar memberikan kesempatan sebanyakbanyaknya agar peserta didik aktif atau lebih giat dalam mengikuti proses pembelajaran. Pembelajaran dengan memanfatkan lingkungan sekitar adalah suatu pembelajaran yang menarik minat peserta didik karena segala sesuatu bahan belajar diambilkan dari lingkungan sekitar. Peserta didik akan lebih mudah memahami materi yang diberikan karena suasana belajar yang diciptakan guru menyenangkan bagi peserta didik

Jika suasana menyenangkan bagi peserta didik, maka peserta didik pun akan lebih termotivasi untuk belajar yang pada akhirnya akan berpengaruh pada meningkatnya hasil belajar peserta didik. Dengan memanfaatkan lingkungan sekitar dalam kegiatan pembelajaran dimungkinkan peserta didik akan lebih menghargai, mencintai dan melestarikan lingkungan alam sekitar sebagai sumber kehidupan.

\section{METODE}

Penelitian tindakan kelas ini dilaksanakan di kelas VII- 4 SMP Negeri 8 Gorontalo yang terletak di Kelurahan Liluwo Kecamatan Kota Tengah Kota Goronralo. Penentuan lokasi penelitian tindakan kelas ini berkaitan dengan status peneliti sebagai guru di SMP Negeri 8 Gorontalo. Yang menjadi subjek penelitian tindakan kelas ini adalah peserta didik kelas VII-4 yang berjumlah 33 orang terdiri dari 15 orang laki-laki dan 18 orang perempuan. Pelaksanaan penelitian tindakan kelas ini bersamaan dengan pelaksanaan proses belajar mengajar pada semester genap tahun pelajaran 2014/2015 . Penelitian ini dilaksanakan dalam dua siklus 
dengan prosedur sebagai berikut; 1) bahan pembelajaran, (d) siswa Menyusun rencana / skenario pembelajaran, menyelesaikan pekerjaan yang telah 2) Menyusun rencana strategi pelaksanaan ditugaskan baik secara individual mau pun observasi di kelas, 3) Melaksanakan kelompok, (e)Guru melakukan penilaian, evaluasi, 4) Mendiskusikan hasil observasi dan (f) menyimpulkan hasil kegiatan peserta dan evaluasi, 5) Mendiskusikan strategi baru didik.

untuk perbaikan tindakan selanjutnya, 6)

Merencanakan tindak lanjut.

\section{PEMANTAUAN DAN EVALUASI}

Prosedur penelitian tindakan ini Untuk mengetahui kesesuaian dilaksanakan dalam dua siklus. Tiap siklus dilaksanakan sesuai perubahan yang ingin dicapai. Pertama dilakukan evaluasi awal (pretest) dan observasi awal untuk mengetahui tindakan yang tepat diberikan untuk meningkatkan hasil pembelajaran. Berdasarkan evalusi awal dan observasi, maka dalam refleksi ditetapkan tindakan yang diberikan yaitu pembelajaran berbasis lingkungan. Dengan berpedoman pada refleksi awal, maka dilaksanakan penelitian tindakan kelas dengan prosedur (1) perencanaan, (2) pelaksanaan tindakan, (3) refleksi pada setiap siklus.

\section{PELAKSANAAN TINDAKAN}

Pelaksanaan tindakan dilaksanakan sesuai perencanaan yaitupembelajaran berbasis lingkungan sesuai perencanaan yang telah disiapkan meliputi: (a)melihat kembali ketepatan penyusunan komponen-komponen dalam rencana pembelajaran, (b) menetapkan pelaksanaan tindakan yang sedang berlangsung akan menghasilkan perubahan yang diinginkan pada peserta didik, dilakukan pemantauan dengan menggunakan lembar pengamatan dari beberapa faktor, yaitu ; a) Faktor KBM, yakni melihat persiapan guru sebelum, selama, dan sesudah mengajar seperti rencana pelaksanaa pembelajaran, materi pembelajaran, proses pembelajaran serta cara penilaian. b) Faktor peserta didik, yaitu melihat respon peserta didik saat pembelajaran berlangsung

Dalam penelitian tindakan kelas ini, refleksi dilaksanakan pada setiap akhir siklus. Dengan demikian rencana perbaikan untuk siklus berikutnya dilaksanakan pada langkah-langkah kegiatan yang masih memerlukan penanganan. Sumber data penelitian ini adalah peserta didik dan seluruh anggota tim peneliti serta data berupa data kualitatif ysang terdiri dari data hasil belajar siswa, dan data hasil observasi strategi yang digunakan, (c) menyiapkan 
pelaksanaan pembelajaran dan data hasil respon peserta didik.

Indikator keberhasilan penelitian tindakan kelas ini adalah hasil belajar peserta didik yang ditunjukkan dengan ketuntasan $85 \%$ atau rata -rata peserta didik mencapai nilai 75 pada setiap kompetensi dasar.

\section{PEMBAHASAN}

Pelaksanaan tindakan kelas dalam penelitian ini berpijak pada langkah-langkah pembelajaran dengan tetap merujuk pada rancangan dan model pembelajaran yang telah ditetapkan. Penelitian tindakan kelas ini dilakukan dalam 2 siklus yang disesuaikan dengan jadwal program semester genap yakni pada bulan Februari sampai dengan bulan April 2015. Materi pembelajaran yang dijadikan acuan penelitian ini pada Siklus I adalah : mendegarkan dan memahami isi wawancara dengan satu tokoh/ nara sumber, menceritakan tokoh idola, menulis pengalaman, dan memahami isi dongeng yang diperdengarkan, sedangkan materi pada siklus II adalah : bertanya jawab dengan teman, mendongeng, menulis pantun, dan berbalas pantun.

\section{HASIL PENELITIAN}

\section{Siklus 1}

Proses pembelajaran pada siklus 1 terdiri dari 4 kali pertemuan/tatap muka. Pertemuan pertama dengan materi wawancara dengan nara sumber, dimulai dengan langkah-langkah sebagai berikut: a) membentuk kelompok peserta didik menjadi 4 - 5 orang, b) Dalam kelompoknya peserta didik menyusun panduan wawancara berdasarkan ketentuan yang telah ditentukan, c) Guru mengajak kelompok menuju ke tempat di luar ruang kelas yang memungkinkan peserta didik untuk belajar, Berdasarkan data hasil penelitian yang diperoleh melalui lembar informasi balikan menunjukkan bahwa pada siklus I proses pelaksanaan tindakan mencapai ketuntasan $70 \%$ dan tes hasil belajar mencapai 75,6 \% (25 orang ). Dengan demikian data ini menunjukkan bahwa harapan yang didinginkan dari pelaksanaan tindakan kelas ini belum memperlihatkan hasil yang maksimal. Selanjutnya pada siklus lanjutan diperoleh data mengenai pelaksanaan tindakan telah mencapai $87,5 \%$ sedangkan tes hasil belajar 87,9\% (29 orang ). Untuk lebih jelasnya data tentang pelaksanaan tindakan dan tes hasil belajar peserta didik dapat dilihat pada tabel berikut ini. 
Data Hasil Penelitian Ditinjau Dari Segi Pelaksanaan Tindakan Dan Tes Hasil Belajar

\begin{tabular}{|c|c|c|c|}
\hline No. & Komponen Pengamatan & Siklus I & Siklus II \\
\hline 1. & Proses pelaksanaan tindakan & $70 \%$ & $87,5 \%$ \\
2. & Tes hasil belajar & $75,6 \%$ & $87,9 \%$ \\
\hline
\end{tabular}

Selanjutnya frekuensi pengamatan yang diperoleh melalui tes hasil belajar mengenai proses pelaksanaan tindakan atau bahwa keberhasilan belajar hanya mencapai pembelajaran dapat dikemukakan seperti 75,6\% yang berarti dari 33 orang peserta berikut :

\section{1) Siklus I}

Secara keseluruhan pelaksanaan tindakan pada siklus I memperoleh nilai prosentasi sebesar $70 \%$, nilai seperti ini belum memenuhi syarat berdasarkan kriteria yang tetapkan sebesar $85 \%$. Rendahnya mutu pembelajarana pada siklus I tersebut disebabkan oleh beberapa aspek yang ternyata belum memenuhi harapan yang didinginkan, misalnya kemampuan guru dalam mengelolah kegiatan pembelajaran hanya mencapai $62,5 \%$. Demikian halnya mengenai ketuntasan peserta didik mencapai 66,6 \%. Aspek lain yang turut berpengaruh adalah hubungan dengan prosedur penilaian yang hanya mencapai $50 \%$. Selain itu aspek yang berhubungan dengan kesan umum pemebelajaran mencapai $62,5 \%$.

Dengan melihat data hasil pengamatan seperti diuraikan ini, sangat jelas memengaruhi mutu hasil belajar. Dari data didik mengikuti evaluasi belajar tedapat 8 orang yang memperoleh nilai di bawah 70 . Berdasarkan kriteria keberhasilan yang ditetapkan, maka jumlah prosentasi sebesar $75,6 \%$ belum dapat dinyatakan berhasil. Oleh karena itu pengujian kembali dilakukan dengan jalan mengadakan diskusi dengan partisipan guna mempelajari hal-hal yang dinilai kurang pada siklus I. Hal ini dimaksudkan untuk mencari alternatif mengenai perbaikan tindakan yang dilakukan pada pelaksanaan siklus II.

\section{2) Siklus II}

Dari hasil pengamatan pelaksanaan tindakan pada Siklus II, diperoleh nilai prosentasi $87,5 \%$ dengan tes hasil belajar $87,9 \%$. Upaya perbaikan ini ternyata memberikan dampak yang begitu besar bagi pencapaian keberhasilan pelaksanaan tindakan. Hal ini ditunjukkan oleh aspekaspek sebagai berikut : kemampuan guru mengelolah kegiatan pembelajaran mencapai 
$79 \%$, ketuntasan peserta didik $75 \%$, aspek yang berhubungan dengan prosedur penilaian $75 \%$, dan kesan umum pembelajaran mencapai $88 \%$. Dari data yang diperoleh dapat ditarik kesimpulan bahwa pelaksanaan tindakan kelas siklus II di nilai berhasil karena telah memenuhi syarat sesuai dengan kriteria keberhasilan yang ditetapkan.

Untuk lebih jelasnya data tentang pelaksanaan KBM dapat dilihat pada tabel berikut.

Data Hasil Pengamatan KBM

\begin{tabular}{|c|c|c|c|}
\hline No. & Komponen Pengamatan & Siklus & Siklus II \\
\hline 1. & kemapuan mengelolah KBM & $62,5 \%$ & $79 \%$ \\
2. & keantusiasan siswa & $66,6 \%$ & $75 \%$ \\
3. & prosedur penilaian & $50 \%$ & $75 \%$ \\
4. & kesan umum pembelajaran & $62,5 \%$ & $88 \%$ \\
\hline
\end{tabular}

\section{PEMBAHASAN}

Pembelajaran berbasis lingkungan merupakan pendekatan yang dapat digunakan dalam proses pembelajaran Bahasa Indonesia. Berdasarkan hasil penelitian, ternyata pembelajaran berbasis lingkungan memiliki nilai tersendiri dalam memacu hasil belajar peserta didik.

Berdasarkan pengamatan intensif mengenai penerapan pembelajaran berbasis lingkungan dalam penelitian tindakan kelas ini, diperoleh suatu gambaran bahwa tindakan efektivitas penerapan pembelajaran berbasis lingkugan sangat tergantung pada guru dalam melaksanakan proses pembelajaran. Faktor inilah yang antara lain dapat menentukan keberhasilan peserta didik dalam belajar.

Gambaran empiris yang telah dikemukakan ini dapat dibuktikan melalui data hasil penelitian, dimana hasil pelaksanaan tindakan pada siklus I baru mencapai $70 \%$. Hal ini di sebabkan karena adanya beberapa aspek yang telah diamati kurang menunjukkan hasil yang memuaskan sehingga dengan demikian mempengaruhi pula hasil belajar peserta didik. Kendala seperti yang telah dikemukakan ini ditunjukkan oleh tingkat keberhasilan evaluasi belajar sebesar 75,6 \%. Ini berarti ketuntasan belajar dapat dinyatakan belum berhasil karena kurang memenuhi kriteria atau keberhasilan yang ditetapkan. 
Memenuhi kondisi yang demikian ini telah diadakan upaya perbaikan mengenai pelaksanaan tindakan yang diarahkan pada beberapa aspek yang dinilai kurang pada siklus I. Upaya perbaikan yang telah dilakukan ini telah menunjukkan hasil yang menggembirakan seperti terlihat prosentase keberhasilan pelaksanaan tindakan meningkat menjadi 87,5 \%. Dengan meningkatnya hasil pelaksanaan tindakan pada siklus II secara serempak diikuti oleh adanya peningkataan pada beberapa aspek yang sebelumnya dinilai kurang pada siklus I, misalnya saja kemampuan guru dalam mengelolah KBM, keantusiasan peserta didik, prosedur penilaian dan kesan umum pembelajaran. Hal seperti ini terlihat jelas pengaruhnya pada kemampuan peserta didik dalam menjawab tes hasil belajar yang secara keseluruhan mencapai $87,9 \%$ Ini membuktikan bahwa pelaksanaan tindakan pada siklus II dinilai berhasil dan memenuhi kriteria keberhasilan yang telah ditetapkan.

\section{PENUTUP}

Dengan memperhatikan hasil analisis data dan pembahasan sebagaimana yang telah diuraikan pada bab sebelumnya, disimpulkan sebagai berikut bahwa a) pembelajaran berbasis lingkungan adalah pembelajaran yang mendekatkan peserta didik pada alam sekitar dan dapat menciptakan suasana belajar yang menyenangkan bagi peserta didik sehingga pembelajaran lebih bermakna, pembelajaran berbasis lingkungan terbukti dapat meningkatkan hasil belajar peserta didik pada mata pelajaran bahasa Indonesia yang ditunjukkan oleh ketuntasan belajar pada siklus II telah mencapai 86,8 \%.

Berdasarkan kesimpulan yang dikemukakan, penulis menyampaikan beberapa saran yakni, a) untuk mencapai hasil yang maksimal, diperlukan ketelitian dan kecermatan guru dalam merencanakan program pembelajaran terutama memilih strategi dan pendekatan yang tepat dalam proses pembelajaran, dan b) dalam proses pembelajaran Bahasa Indonesia hendaknya guru mengupayakan memanfaatkan lingkungan sebagai sumber belajar. 


\section{DAFTAR PUSTAKA}

Arikunto,dkk. 2006. Penelitian Tindakan Kelas. Jakarta: Bumi Aksara.

Baharudin dan Wahyuni. 2007. Teori belajar dan Pembelajaran. Jogjakarta: ArRuzz Media.

Dimyati dan Mudjiono. 1994. Belajar dan Pembelajaran, Jakarta : Rineka Cipta.

Depdiknas. 2003. Undang-undang Republik Indonesia tentang Sistem pendidikan Nasional. Jakarta: Depdiknas.

Ghony, Djunaidi. 2008. Penelitian Tindakan Kelas. Malang:UIN Malang Press.

Hamalik, Oemar. 2001. Proses Belajar Mengajar. Bandung : Bumi Aksara.

Kunandar, M.Si. 2008. Langkah-langkah Penelitian Tindakan Kelas. Jagakarsa: Rajawali Press.

Loekmono, Lobby. 1994. Belajar Bagaimana Belajar. Salatiga: Gunung Mulia.

Nurhadi, dkk. 2004. Pembelajaran Kontekstual. Malang: Universitas Malang.

Sanjaya, Dr. 2008. Strategi Pembelajaran. Jakarta: Kencana Premada Media Grup.
Sagala, Syaiful. 2003. Konsep dan Makna Pembelajaran. Bandung : Alfabeta Th. Suparman, Kardi. 2004. Pengajaran Langsung. Surabaya: University Press.

Syamsudin dan Damaianti.2006.Metode Penelitian Pendidikan Bahasa. Bandung:Rosda.

Susilo.2007. Panduan Penelitian Tindakan Kelas. Yokyakarta: Pustaka Book Publiser.

Sagala, Syaiful. 2003. Konsep dan Makna Pembelajaran. Bandung : Alfabeta Th.

Sanjaya, Wina. 2006. Strategi Pembelajaran. Jakarta: Kencana Prenada Media Grup. 